\title{
Expression Analysis of PAC1-R and PACAP Genes in Zebrafish Embryos
}

\author{
David Alexandre • Jessy Alonzeau • Brent R. Bill • \\ Stephen C. Ekker • James A. Waschek
}

Received: 1 April 2010 /Accepted: 23 May 2010 / Published online: 5 June 2010

(C) The Author(s) 2010. This article is published with open access at Springerlink.com

\begin{abstract}
This study describes the expression of the pituitary adenylate cyclase-activating polypeptide (PACAP1 and PACAP2) and PAC1 receptor genes (PAC1a-R and PAClb$\mathrm{R}$ ) in the brain of zebrafish (Danio rerio) during development. In situ hybridization of the 24- and 48-hpf embryos revealed that PACAP genes were expressed in the telencephalon, the diencephalon, the rhombencephalon, and the neurons in the dorsal part of the spinal cord. PACAP2 mRNA appears to be the most abundant form during brain development. The two PAC1-R subtypes showed a similar expression pattern: mRNAs were detected in the forebrain, the thalamus, and the rhombencephalon. However, in the tectum, only PAC1b$\mathrm{R}$ gene was detected. These results suggest that, in fish, PACAP may play a role in brain development.
\end{abstract}

D. Alexandre $(\bowtie) \cdot J$. Alonzeau

INSERM U982, University of Rouen,

Mont-Saint-Aignan, France

e-mail: david.alexandre@univ-rouen.fr

D. Alexandre $\cdot$ J. Alonzeau

DC2N Laboratory, University of Rouen,

Mont-Saint-Aignan, France

B. R. Bill J. A. Waschek

Semel Institute, D. Geffen School of Medicine,

University of California,

Los Angeles, CA, USA

B. R. Bill · J. A. Waschek

Department of Psychiatry, D. Geffen School of Medicine,

University of California,

Los Angeles, CA, USA

S. C. Ekker

Department of Genetics, Cell Biology and Development,

University of Minnesota,

Minneapolis, MN, USA
Keywords Zebrafish · PACAP receptors · Ontogeny · Central nervous system

\section{Introduction}

Pituitary adenylate cyclase-activating polypeptide (PACAP) was first isolated from the ovine hypothalamus on the basis of its ability to stimulate cyclic AMP formation in rat pituitary cells (Miyata et al. 1989). PACAP exists in two amidated forms of 38 (PACAP38) or 27 (PACAP27) amino acid residues and is structurally related to be a member of the vasoactive intestinal polypeptide (VIP), glucagon, secretin, and growth hormone-releasing hormone superfamily. PACAP acts through three types of $\mathrm{G}$ protein-coupled receptors. Two of these receptors, VPAC1-R and VPAC2-R, bind PACAP and VIP with equal affinity, whereas the third receptor, PAC1-R, selectively binds PACAP with high affinity (Alexandre et al. 1999; Alexandre et al. 2002; Inagaki et al. 1994; Spengler et al. 1993; Sreedharan et al. 1995). The sequence of PACAP has been highly conserved during evolution; human PACAP38 peptide shares 97\% homology with the frog PACAP38 (Alexandre et al. 2000) and 90\% with the salmon counterpart (Parker et al. 1993). In some species like in zebrafish, two PACAP genes were identified and termed PACAP1 and PACAP2 (Fradinger and Sherwood 2000; Wang et al. 2003). PACAP1 and PACAP2 peptides share $82 \%$ of identities, and $84 \%$ and $92 \%$, respectively, with the mammalian PACAP38 peptide. The presence of two copies of these genes in the genome is likely due to genome duplication during evolution (Vogel 1998). Moreover, two PAC1-receptors, namely PAC1a-R and PAClb-R, were also identified in zebrafish (Fradinger et al. 2005).

The distribution of PACAP and PAC1R mRNAs has been investigated in the embryonic central nervous system 
of species such as mice (Waschek et al. 1998), xenopus (Hu et al. 2002), and zebrafish (Krueckl et al. 2003). In adult humans, PAC1-R gene is mainly expressed in the olfactory bulb, the cerebral cortex, the supraoptic nucleus, and the cerebellum (Vigh et al. 1991). PACAP is expressed in neurons of the cerebral cortex, the amygdala, and the thalamus, and is particularly abundant in the hypothalamic nucleus where PACAP acts as a hypophysiotropic factor on pituitary cells (Rawlings and Hezareh 1996). The expression patterns in the adult brain suggest that PACAP acts as a neurotransmitter and/or a neuromodulator. Indeed, PACAP also exerts numerous effects on adult brain, and is involved in circadian rhythms (Mertens et al. 2007) (Colwell et al. 2004) and learning and memory processes, as well as in the neurite outgrowth, cell differentiation, and proliferation (Vaudry et al. 2009). However, relatively little information is available concerning the functional roles of the PACAP during development. Thus, in the present study, we examined by using whole-mount in situ hybridization in the zebrafish embryos the expression patterns of genes encoding the two PACAP precursors (PACAP1 and PACAP2) and PAC1 receptors (PAC1Ra and PAC1Rb) during the early development.

\section{Materials and Methods}

\section{Whole-Mount in Situ Hybridization}

Zebrafish embryos were collected during natural spawning periods and were cultured in egg water. Embryonic stages are represented as the unit hour post-fertilization (hpf) at 24 and 48 hpf. Full-length cDNAs encoding PACAPs and their receptors were amplified using the total RNA from the 48-hpf zebrafish embryos and were cloned in pCR4-TOPO vector for in vitro transcription using T3 and T7 RNA polymerases to make sense and antisense digoxigenin (DIG)-labeled riboprobes (Roche Applied Science, France).

For the whole-mount in situ hybridization experiments, about ten to 15 zebrafish embryos were fixed in $4 \%$ paraformaldehyde, washed in phosphate buffered saline (PBS) containing $0.2 \%$ Tween 20, and then incubated in hybridization buffer $(50 \%$ formamide, $5 \mathrm{X}$ SSC, $0.5 \mathrm{mg} / \mathrm{L}$ ribosomal RNA, $0.1 \%$ Tween 20 ) with DIG-labeled RNA probe at $65^{\circ} \mathrm{C}$ overnight. Embryos were washed in PBS-Tween buffer and incubated with an anti-DIG antibody conjugated to alkaline phosphatase. The hybridization signals were detected using the NBT/ BCIP colorimetric system according to the manufacturer's instructions (Roche Applied Science, France). Each in situ hybridization experiment was performed two times.

\section{Gene Quantification}

To determine the expression levels of the PACAP and PAC1$\mathrm{R}$ genes, quantitative polymerase chain reaction (Q-PCR) was performed on the 24- and 48-hpf embryos. Total RNA was isolated from 20 embryos per stage using TRIzol reagent (Invitrogen, France) and quantified by UV absorbance, and $1 \mu \mathrm{g}$ of RNA was reverse transcribed into cDNA prior to PCR with the ImProm-II reverse transcription system (Promega, France). PCR primers for PACAP1 were: forward, 5' AGGCACGCTGACGGGATGTT3'and reverse, 5' TGTCATCTTCTGTTGTGCTCCC 3 ', and correspond to nucleotides 706-725 and 808-829 of the mRNA (GenBank accession number NM_152885.1), respectively. PCR primers for PACAP2 were: forward, 5'CACCCGAGTCGCATC CAACA3' and reverse, 5'CGTGCAGTAGGCGCTG TAGTG3', and correspond to nucleotides 235-254 and 338-358 of the mRNA (GenBank accession number NM_214715.1). PCR primers for PAC1a-R were: forward, 5'CCATCATCGGCTGGGGAACGC3' and reverse, 5' TCACCCACCAGAGGGCAGTGT3', and correspond to nucleotides 932-952 and 1028-1048 of the mRNA (GenBank accession number NM_001142925.1). PCR primers for PAC1b-R were: forward, 5'GATGATCCCAACAGT GAACCG3' and reverse, 5'ACAGGGCATCCAGA CAACTTGA3', and correspond to nucleotides 130-150 and 210-231 of the mRNA (GenBank accession number XM_677888.3). Elongation factor 1-alpha (EF1- $\alpha)$ primers, used as an external control, were: forward, 5'CTGGAGGC CAGCTCAAACAT3' and reverse, 5'ATCAAGAAGAG TAGTACCGCTAGCATTAC3', and correspond to nucleotides 678-697 and 736-764 of the mRNA (GenBank accession number NM_131263.1). Q-PCR was performed using $6.5 \mu \mathrm{L}$ of $2 \mathrm{X}$ SYBR Green PCR Master Mix (Applied Biosystems, France), $300 \mathrm{nM}$ of each primers, and $3 \mu \mathrm{L}$ of 1:20 diluted template for standard reactions or $3 \mu \mathrm{L}$ of nuclease-free water for negative controls. Real-time PCR reaction cycles were: $2 \mathrm{~min}$ at $94^{\circ} \mathrm{C}$, then 45 cycles of $15 \mathrm{~s}$ at $94^{\circ} \mathrm{C}, 25 \mathrm{~s}$ at $60^{\circ} \mathrm{C}$, and $20 \mathrm{~s}$ at $72^{\circ} \mathrm{C}$, with a dissociation stage at the end of the amplification by using an ABI Prism 9700HT Fast Real-Time PCR System (Applied Biosystems, France).

\section{Results}

PAC1-R and PACAP Gene Expressions

Q-PCR was performed on the 24- and 48-hpf embryos, as well as in the adult zebrafish brain (Fig. 1). During development, the two PAC1-Rs showed similar level of detection, whereas in adult the PAClb-R is detected at $50 \%$ higher level than the PACla receptor. Concerning the 
Figure 1 Quantifications of PAC1a-R, PAC1b-R, PACAP1, and PACAP2 mRNA during the early development in the 24and 48-hpf embryos and adult zebrafish. Elongation factor-1 gene was used as internal reference to normalize mRNA quantification. Data are means $\pm \mathrm{SE}$ of three experiments

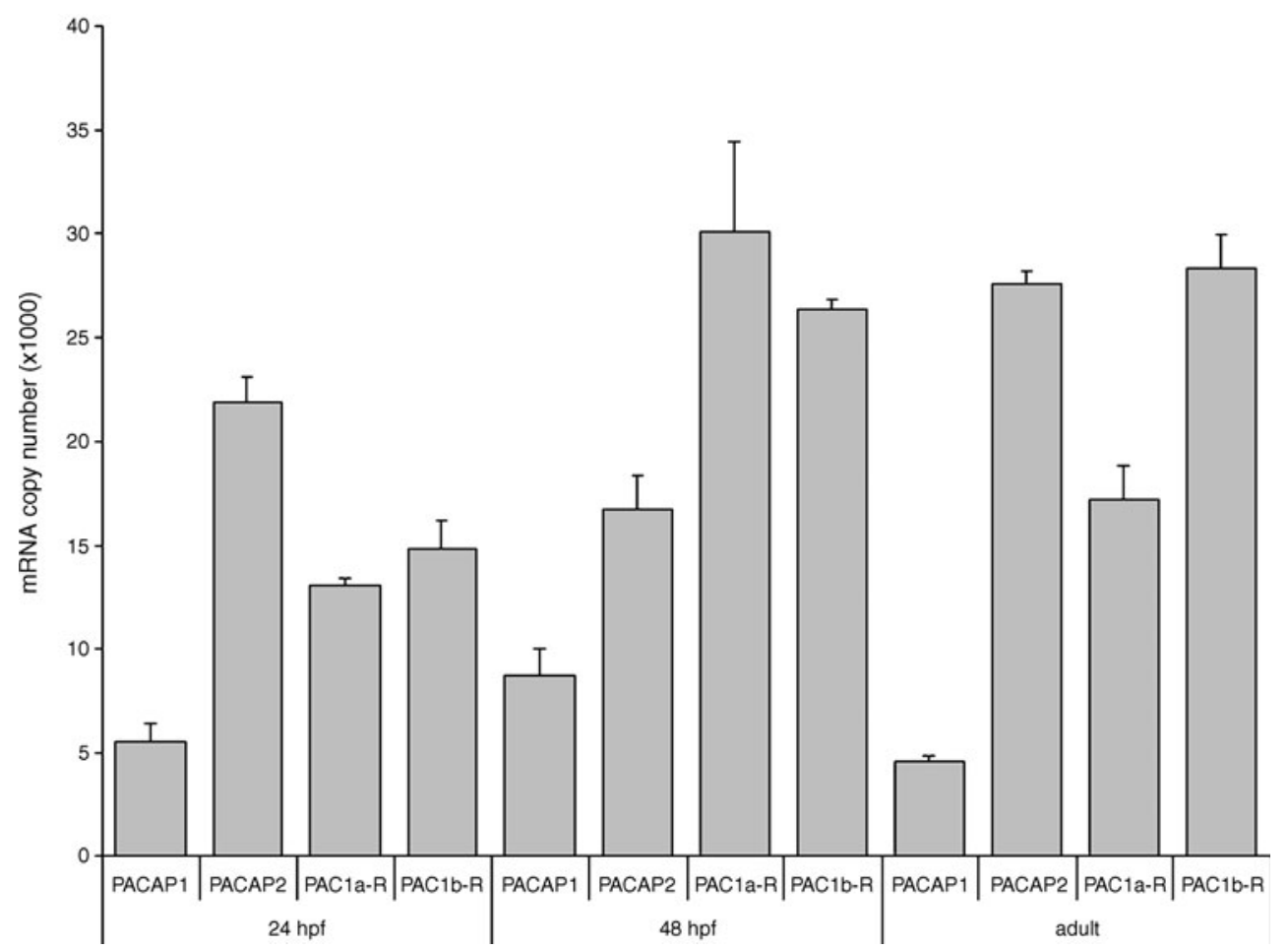

PACAP genes, PACAP2 mRNA appeared as the predominant form in embryos and in adult. PACAP2 gene expression was detected at four-, two-, and six-fold levels than that of PACAP1 in $24 \mathrm{hpf}, 48 \mathrm{hpf}$, and adult zebrafish, respectively (Fig. 1). Normalization of the quantitative PCR results with the housekeeping gene EF1- $\alpha$, which is known to be constant during embryogenesis, revealed that PAC1 receptor mRNA level was two times higher at $48 \mathrm{hpf}$ than at $24 \mathrm{hpf}$, whereas the expression of PACAP genes did not change. In fact, PACAP1 gene expression increased and the PACAP2 gene expression decreased between 24 and 48 hpf.



Figure 2 a Representative photomicrograph showing the expression of PACAP1 messenger RNA in the 24-hpf embryo. b No significant hybridization signal was seen with a PACAP1 sense probe. Cerebel-

\section{Gene Expression Patterns}

The expressions of PACAP and PAC1-R genes were investigated by using in situ hybridization with specific DIG-labeled probes in the early development on the 24and 48-hpf zebrafish embryos. Figure 2 showed that PACAP1 gene is mainly expressed in the neural crest, the floor plate, and the dorsal neurons of the spinal cord. PACAP2 messenger RNAs were first detected in the spinal cord, the rhombencephalon, and the telencephalon (Fig. 3a, b). Then, in the 48-hpf embryos, the hybridization signal revealed the presence of mRNA in several areas identified



lum $C$, diencephalon $D$, floor plate $F P$, mesencephalon $M$, neural crest $N C$, telencephalon $T$, rhombencephalon $R$, spinal cord $S P$, and yolk sac $Y S$ 
Figure 3 Photomicrographs showing the expression of (a, b) and 48-hpf (c, d) embryos. Cerebellum $C$, diencephalon $D$, floor plate $F P$, hypothalamus $H T$,

mesencephalon $M$, telencephalon $T$, thalamus $T H$, retina $R T$, rhombencephalon $R$, spinal cord $S P$, tectum $T C$, and yolk sac $Y S$ PACAP2 mRNA in the 24-hpf


from the entire embryo and frontal sections. A high to moderate expression of PACAP2 gene was found in the telencephalon, the diencephalon, the thalamus, the hypothalamus, the rhombencephalon, the retina, and the tectum
(Fig. 3c, d). Concerning the PAC1 receptors, PACla-R antisense probe revealed a hybridization signal mainly in the diencephalon and the telencephalon in the 24-hpf embryos (Fig. 4a). At the same developmental stage, 
Figure 4 PAC1-R gene expression in the 24-hpf (a-c) and

48-hpf (b-d) zebrafish embryos. Whole-mount in situ hybridization by using a DIG-labeled PACla-R antisense probe $(\mathbf{a}, \mathbf{b})$ or a PAC1b-R antisense probe $(\mathbf{c}, \mathbf{d})$. Diencephalon $D$, hypothalamus $H T$, midbrain-hindbrain boundary $M H B$, rhombencephalon $R$, telencephalon $T$, thalamus $T H$, and tectum $T C$
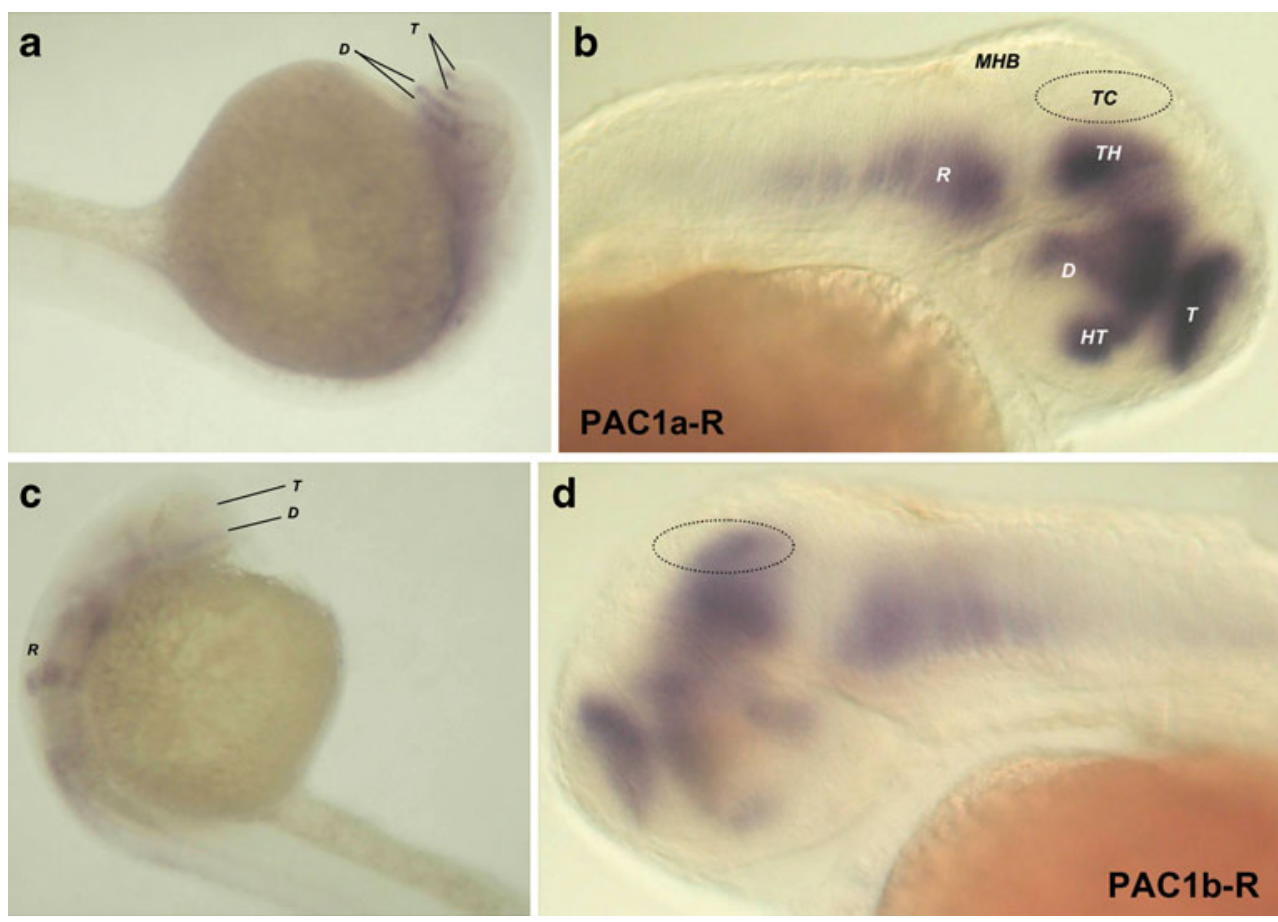

PAC1b-R is expressed in the diencephalon and the rhombencephalon, whereas only faint expression was seen in the telencephalon (Fig. 4c). At later stage, in the 48-hpf zebrafish embryos, both PAC1receptors showed similar expression profiles with a strong labeling in the telencephalon, the thalamus, and the diencephalon (Fig. 4b, d). A moderate signal was found in the rhombencephalon, whereas the metencephalon and the retina were devoid of hybridization signals of the two PAC1 receptors. In the hypothalamus, PAC1b-R is expressed at low levels compared to the PACla-R. The main difference between the two PAC1 receptor expressions was found in the tectum area in which only the PAClb-R is expressed, whereas no signal was detected with the PACla-R probe in this region (Fig. 4b, d).

\section{Discussion}

In this study, the expression of the PACAPergic system was examined during the development of the zebrafish Danio rerio in the pharyngula period corresponding to the 24 - to 48-hpf embryos. Kimmel and collaborators described this period as an important time of development corresponding to the establishment of rudiment organs, for example, a functional heart and circulation, and pigmented retinal epithelium that differentiates and surrounds the lens. Embryos at 24 hpf have 30 somites. Rapid morphogenesis then sculpts the nervous system, which expands anteriorly and results into a brain with five lobes and ventricles. This is the time of development when one can most readily compare the morphologies of embryos of diverse vertebrates (Kimmel et al. 1995).

Then, the expression levels of PACAP1, PACAP2, PACla-R, and PAC1b-R genes were investigated by using real-time PCR technique on reverse transcribed mRNA from the 24- and 48-hpf embryos and adult zebrafish. The EF1- $\alpha$ was used as a housekeeping gene since its expression was shown to be constant during the development of zebrafish (Tang et al. 2007). PACAP2 mRNA was the principal form detected in embryos in comparison to the expression level of PACAP1 gene (Fig. 1). This result is consistent with the 24-h staining period needed to detect the PACAP1 DIG-labeled probe versus the 30-40-min staining period with the PACAP2 probe in whole-mount in situ hybridization (Figs. 2 and 3). In adult, PACAP2 gene expression was detected at six-fold high levels than the PACAP1 gene, indicating that PACAP1 might play the predominant role during the embryogenesis. Moreover, PACAP1 mRNA is mainly expressed in the neural tube in all species examined, suggesting an essential role in the early neural patterning, in part through protein kinase A-mediated antagonisms of sonic hedgehog signaling (Lelievre et al. 2008).

In all species examined, including zebrafish, PACAP and PAC1R genes are expressed in at particularly high levels in the posterior part of the embryonic nervous system, corresponding to the hindbrain and the spinal cord. At $48 \mathrm{hpf}$, PACAP and PAC1-R mRNA are widely detected in the central nervous system of zebrafish from the telencephalon to the rhombencephalon through the diencephalon and the mesencephalon. Only the metencephalon was devoid of 
mRNA encoding PACAP and its receptors (Figs. 2, 3, and 4). Another group detected expression of the PACAP1 gene in the zebrafish cerebellar primordium at $24 \mathrm{hpf}$, perhaps owing to a higher level of assay sensitivity (Krueckl et al. 2003)

A comparison of distribution of PACAP and PAC1-R mRNA in the embryos of different species reveals slight differences. At the same developmental stage, corresponding to E10-15 in mice (Sheward et al. 1998; Waschek et al. 1998), stage 25-35 in Xenopus laevis (Hu et al. 2001), and pharyngula stage in zebrafish (Krueckl et al. 2003, our study), the expression patterns of PACAP and PAC1-R in xenopus appeared more restricted than in mice. Indeed, the PAC1-R gene was not expressed in the telencephalon and the metencephalon, and PACAP gene was expressed only in the hindbrain at the rhombencephalon level and in the spinal cord. In mice, peptide and receptor mRNA were identified in all different parts of the brain suggesting that fish showed a gene expression pattern closer to the mice than to the xenopus. These apparent differences in mice/fish and xenopus are probably due to differing temporal patterns of gene expression in brain subregions in these species.

In situ hybridization analysis revealed a similar expression profile of the two zebrafish PAC1-R genes except in the tectum. In the mesencephalon, only PAC1b-R mRNA was detected in the tectum area. In any case, the expression patterns suggest that PACAP peptide could be implicated in the visual information analysis and/or circadian rhythm regulation (Hannibal and Fahrenkrug 2004; Yanez et al. 2009).

To investigate the function of PACAP during the early development, we injected mRNA encoding PACAP in fish embryos and tried to knockdown PACAP gene expression by using morpholinos. Using these approaches, we could not see any obvious morphological changes in fish embryos (data not shown). However, Sherwood's group reported a severe phenotype consisting of a reduction of brain size, a modification of the midbrain-hindbrain boundary and smaller eyes, after injection of morpholinos against PACAP1 and PACAP2 genes (Wu et al. 2006). This difference of results between our teams may be due to the specific morpholinos used and/or the quantity of morpholinos injected. Finally, Blechman and coworkers did not see any morphological changes after morpholino injection, but demonstrated that PACAP and PAC1R are highly expressed in hypothalamus and are involved in the differentiation of neuron precursors into dopaminergic and oxytocinergic neurons (Blechman et al. 2007). In mice, targeted deletion of PACAP did not result in any obvious phenotype. However, PACAP gene deletion revealed the importance of this neuropeptide in many functions, such as the regulation of circadian rhythms (Colwell et al. 2004;
Hannibal et al. 2008), ontogeny of the cerebellum (Allais et al. 2007), testicular aging (Lacombe et al. 2006), and energy metabolism (Sherwood et al. 2007; Tomimoto et al. 2008).

In the present study, we have described the presence of PACAP and its cognate receptors mRNA in different structures of the developing nervous system, suggesting an important function for this peptide during the brain development in fish, as well as in higher vertebrates.

Acknowledgments This work was supported by grants from the Conseil Régional de Haute-Normandie and National Institutes of Health grants CA110384, HD34475, and HD04612.

Open Access This article is distributed under the terms of the Creative Commons Attribution Noncommercial License which permits any noncommercial use, distribution, and reproduction in any medium, provided the original author(s) and source are credited.

\section{References}

Alexandre D, Anouar Y, Jegou S, Fournier A, Vaudry H (1999) A cloned frog vasoactive intestinal polypeptide/pituitary adenylate cyclase-activating polypeptide receptor exhibits pharmacological and tissue distribution characteristics of both $\mathrm{VPAC}_{1}$ and $\mathrm{VPAC}_{2}$ receptors in mammals. Endocrinology 140:1285-1293

Alexandre D, Vaudry H, Jegou S, Anouar Y (2000) Structure and distribution of the mRNAs encoding pituitary adenylate cyclaseactivating polypeptide and growth hormone-releasing hormonelike peptide in the frog, Rana ridibunda. J Comp Neurol 421:234-246

Alexandre D, Vaudry H, Grumolato L, Turquier V, Fournier A, Jegou S, Anouar Y (2002) Novel splice variants of type I pituitary adenylate cyclase-activating polypeptide receptor in frog exhibit altered adenylate cyclase stimulation and differential relative abundance. Endocrinology 143:2680-2692

Allais A, Burel D, Isaac ER, Gray SL, Basille M, Ravni A, Sherwood NM, Vaudry H, Gonzalez BJ (2007) Altered cerebellar development in mice lacking pituitary adenylate cyclase-activating polypeptide. Eur J Neurosci 25:2604-2618

Blechman J, Borodovsky N, Eisenberg M, Nabel-Rosen H, Grimm J, Levkowitz G (2007) Specification of hypothalamic neurons by dual regulation of the homeodomain protein Orthopedia. Development 134:4417-4426

Colwell CS, Michel S, Itri J, Rodriguez W, Tam J, Lelievre V, Hu Z, Waschek JA (2004) Selective deficits in the circadian light response in mice lacking PACAP. Am J Physiol Regul Integr Comp Physiol 287:R1194-1201

Fradinger EA, Sherwood NM (2000) Characterization of the gene encoding both growth hormone-releasing hormone (GRF) and pituitary adenylate cyclase-activating polypeptide (PACAP) in the zebrafish. Mol Cell Endocrinol 165:211-219

Fradinger EA, Tello JA, Rivier JE, Sherwood NM (2005) Characterization of four receptor cDNAs: PAC1, VPAC1, a novel PAC1 and a partial GHRH in zebrafish. Mol Cell Endocrinol 231:49-63

Hannibal J, Fahrenkrug J (2004) Target areas innervated by PACAPimmunoreactive retinal ganglion cells. Cell Tissue Res 316:99-113

Hannibal J, Brabet P, Fahrenkrug J (2008) Mice lacking the PACAP type I receptor have impaired photic entrainment and negative masking. Am J Physiol Regul Integr Comp Physiol 295:R2050 2058 
Hu Z, Lelievre V, Rodriguez WI, Tam J, Cheng JW, Cohen-Cory S, Waschek JA (2001) Embryonic expression of pituitary adenylyl cyclase-activating polypeptide and its selective type I receptor gene in the frog Xenopus laevis neural tube. J Comp Neurol 441:266-275

Hu Z, Lelievre V, Rodriguez WI, Cheng JW, Waschek JA (2002) Comparative distributions of pituitary adenylyl cyclase-activating polypeptide and its selective type I receptor mRNA in the frog (Xenopus laevis) brain. Regul Pept 109:15-26

Inagaki N, Yoshida H, Mizuta M, Mizuno N, Fujii Y, Gonoi T, Miyazaki J, Seino S (1994) Cloning and functional characterization of a third pituitary adenylate cyclase-activating polypeptide receptor subtype expressed in insulin-secreting cells. Proc Natl Acad Sci USA 91:2679-2683

Kimmel CB, Ballard WW, Kimmel SR, Ullmann B, Schilling TF (1995) Stages of embryonic development of the zebrafish. Dev Dyn 203:253-310

Krueckl SL, Fradinger EA, Sherwood NM (2003) Developmental changes in the expression of growth hormone-releasing hormone and pituitary adenylate cyclase-activating polypeptide in zebrafish. J Comp Neurol 455:396-405

Lacombe A, Lelievre V, Roselli CE, Salameh W, Lue YH, Lawson G, Muller JM, Waschek JA, Vilain E (2006) Delayed testicular aging in pituitary adenylate cyclase-activating peptide (PACAP) null mice. Proc Natl Acad Sci USA 103:3793-3798

Lelievre V, Seksenyan A, Nobuta H, Yong WH, Chhith S, Niewiadomski P, Cohen JR, Dong H, Flores A, Liau LM, Kornblum HI, Scott MP, Waschek JA (2008) Disruption of the PACAP gene promotes medulloblastoma in ptc1 mutant mice. Dev Biol 313:359-370

Mertens I, Husson SJ, Janssen T, Lindemans M, Schoofs L (2007) PACAP and PDF signaling in the regulation of mammalian and insect circadian rhythms. Peptides 28:1775-1783

Miyata A, Arimura A, Dahl RR, Minamino N, Uehara A, Jiang L, Culler MD, Coy DH (1989) Isolation of a novel 38 residuehypothalamic polypeptide which stimulates adenylate cyclase in pituitary cells. Biochem Biophys Res Commun 164:567-574

Parker DB, Coe IR, Dixon GH, Sherwood NM (1993) Two salmon neuropeptides encoded by one brain cDNA are structurally related to members of the glucagon superfamily. Eur J Biochem 215:439-448

Rawlings SR, Hezareh M (1996) Pituitary adenylate cyclase-activating polypeptide (PACAP) and PACAP/vasoactive intestinal polypeptide receptors: actions on the anterior pituitary gland. Endocr Rev 17:4 29

Sherwood NM, Adams BA, Isaac ER, Wu S, Fradinger EA (2007) Knocked down and out: PACAP in development, reproduction and feeding. Peptides 28:1680-1687
Sheward WJ, Lutz EM, Copp AJ, Harmar AJ (1998) Expression of PACAP, and PACAP type 1 (PAC1) receptor mRNA during development of the mouse embryo. Brain Res Dev Brain Res 109:245-253

Spengler D, Waeber C, Pantaloni C, Holsboer F, Bockaert J, Seeburg PH, Journot L (1993) Differential signal transduction by five splice variants of the PACAP receptor. Nature 365:170-175

Sreedharan SP, Huang JX, Cheung MC, Goetzl EJ (1995) Structure, expression, and chromosomal localization of the type I human vasoactive intestinal peptide receptor gene. Proc Natl Acad Sci USA 92:2939-2943

Tang R, Dodd A, Lai D, McNabb WC, Love DR (2007) Validation of zebrafish (Danio rerio) reference genes for quantitative real-time RT-PCR normalization. Acta Biochim Biophys Sin (Shanghai) 39:384-390

Tomimoto S, Ojika T, Shintani N, Hashimoto H, Hamagami K, Ikeda K, Nakata M, Yada T, Sakurai Y, Shimada T, Morita Y, Ishida C, Baba A (2008) Markedly reduced white adipose tissue and increased insulin sensitivity in adcyap1-deficient mice. J Pharmacol Sci 107:41-48

Vaudry D, Falluel-Morel A, Bourgault S, Basille M, Burel D, Wurtz O, Fournier A, Chow BK, Hashimoto H, Galas L, Vaudry H (2009) Pituitary adenylate cyclase-activating polypeptide and its receptors: 20 years after the discovery. Pharmacol Rev 61:283357

Vigh S, Arimura A, Koves K, Somogyvari-Vigh A, Sitton J, Fermin CD (1991) Immunohistochemical localization of the neuropeptide, pituitary adenylate cyclase-activating polypeptide (PACAP), in human and primate hypothalamus. Peptides 12:313-318

Vogel G (1998) Doubled genes may explain fish diversity. Science 281(1119): 1121

Wang Y, Wong AO, Ge W (2003) Cloning, regulation of messenger ribonucleic acid expression, and function of a new isoform of pituitary adenylate cyclase-activating polypeptide in the zebrafish ovary. Endocrinology 144:4799-4810

Waschek JA, Casillas RA, Nguyen TB, DiCicco-Bloom EM, Carpenter EM, Rodriguez WI (1998) Neural tube expression of pituitary adenylate cyclase-activating peptide (PACAP) and receptor: potential role in patterning and neurogenesis. Proc Natl Acad Sci USA 95:9602-9607

Wu S, Adams BA, Fradinger EA, Sherwood NM (2006) Role of two genes encoding PACAP in early brain development in zebrafish. Ann NY Acad Sci 1070:602-621

Yanez J, Busch J, Anadon R, Meissl H (2009) Pineal projections in the zebrafish (Danio rerio): overlap with retinal and cerebellar projections. Neuroscience 164:1712-1720 